\title{
Facial Sadness Recognition is Modulated by Estrogen Receptor Gene Polymorphisms in Healthy Females
}

\author{
Mayra Gutiérrez-Muñoz ${ }^{1}$ (), Martha E. Fajardo-Araujo ${ }^{2}$, Erika G. González-Pérez ${ }^{2}$, \\ Victor E. Aguirre-Arzola ${ }^{3}$ (D) and Silvia Solís-Ortiz ${ }^{2, *(D)}$ \\ 1 Facultad de Psicología, Universidad Autónoma de Nuevo León, Monterrey, Nuevo León 66451, Mexico; \\ mlgm.lcp@gmail.com \\ 2 Departamento de Ciencias Médicas, Universidad de Guanajuato, León, Guanajuato 37320, Mexico; \\ mfajardo@ugto.mx (M.E.F.-A.); eg.gonzalezperez@ugto.mx (E.G.G.-P.) \\ 3 Facultad de Agronomía, Universidad Autónoma de Nuevo León, Monterrey, Nuevo León 66451, Mexico; \\ victor.aguirrearz@uanl.edu.mx \\ * Correspondence: silviasolis17@prodigy.net.mx; Tel.: +52-477-714-5859 (ext. 4671); Fax: +52-477-716-7623
}

Received: 1 November 2018; Accepted: 4 December 2018; Published: 7 December 2018

\begin{abstract}
Polymorphisms of the estrogen receptor ESR1 and ESR2 genes have been linked with cognitive deficits and affective disorders. The effects of these genetic variants on emotional processing in females with low estrogen levels are not well known. The aim was to explore the impact of the ESR1 and ESR2 genes on the responses to the facial emotion recognition task in females. Postmenopausal healthy female volunteers were genotyped for the polymorphisms Xbal and PvuII of ESR1 and the polymorphism rs1256030 of ESR2. The effect of these polymorphisms on the response to the facial emotion recognition of the emotions happiness, sadness, disgust, anger, surprise, and fear was analyzed. Females carrying the $\mathrm{P}$ allele of the PvuII polymorphism or the $\mathrm{X}$ allele of the Xbal polymorphism of ESR1 easily recognized facial expressions of sadness that were more difficult for the women carrying the $\mathrm{p}$ allele or the $\mathrm{x}$ allele. They displayed higher accuracy, fast response time, more correct responses, and fewer omissions to complete the task, with a large effect size. Women carrying the ESR2 C allele of ESR2 showed a faster response time for recognizing facial expressions of anger. These findings link ESR1 and ESR2 polymorphisms in facial emotion recognition of negative emotions.
\end{abstract}

Keywords: menopause; ESR1; ESR2; emotion; recognition; sadness

\section{Introduction}

Facial emotion recognition is essential for efficient social interactions [1]. Facial expressions are a group of emotions that includes happiness, sadness, anger, fear, disgust, and surprise [2]. These emotions have been widely examined to describe the brain areas that modulate them [3], as well as the detection of deficits in the recognition of the facial expressions of emotion in aging [4]. The amygdala is part of the neural circuitry crucial for emotion $[5,6]$ and is involved in fear [7], sadness, and happiness [8], whereas surprised faces are associated with greater activity in the right postcentral gyrus and left posterior insula [9]. The insula is also activated by a broad range of disgust-related stimuli, such as facial expressions of disgust [10,11]. Some studies have shown evidence for sex differences in the identification and processing of emotional facial expressions, including the recognition of emotion [12]. Females tend to display higher accuracy in the identification of facial expression than men $[13,14]$. Women are also more prone to suffer from affective temperament dysregulation and suicidal behaviors $[15,16]$, which are considered psychopathological diseases that impact the quality of life [17]. Genetic factors have been implicated in the manifestation of these 
disorders, although the evidence is unclear. It has been found that sex differences influence the manifestation of depression and related disorders, such as anxiety, conduct disorder, and suicidality, and might alter the effects of genetic polymorphisms of the serotonergic system [18]. The monoamine oxidase-A linked polymorphic region (MAO-A), which alters the degradation serotonin and other amine neurotransmitters, has been related with risk for depression and anxiety disorders in postmenopausal women [19]. However, a study did not find an association between MAO-A3 gene variants and increased suicidal risk in patients with chronic migraine and affective temperamental dysregulation measured with specific questionnaires [20].

In addition, there is evidence that sex hormones influence emotional processing [21,22]. For instance, it has been observed that females in the periovulatory phase, which is distinguished by elevated levels of estrogen, were significantly more accurate in recognizing fearful faces than females in the follicular phase of the menstrual cycle with lower estrogen levels [23]. One study showed that, in young women, the percentage of errors was significantly higher for the emotional facial expressions of sadness and disgust in the follicular phase than in the menstrual phase [24]. Sadness was more accurately recognized during the early follicular phase, which is distinguished by lower levels of estrogen, than during the luteal phase of the menstrual cycle [25]. A negative association was reported between facial disgust recognition and estradiol levels, and higher progesterone levels were related with slowing responses to the expression of anger, sadness, happiness, and neutral expressions in naturally cycling females [26].

These studies highlight the role of ovarian hormones, particularly estrogens, in the emotional processing of faces [22], but the role of estrogen receptors in the recognition of emotional expressions is rarely studied, particularly during postmenopause. In women, this stage is distinguished by low levels of estrogen and progesterone, producing significant physiological effects $[27,28]$ that have been associated with several adverse outcomes, such as depressive symptoms [29,30], anxiety and severe quality-of-life impairment [31], and complaints of changes in cognitive functions [32]. The estrogen receptor genes are potential genes that might impact the facial emotion recognition due to their relations with cognition [33] and emotion [34]. The estrogen receptor (ER) is a ligand-intensify protein that is a partner of the steroid nuclear receptor family [35-37]. Estrogen actions are mediated across estrogen receptors, ER $\alpha$, ER $\beta$, which are fully dispensed over the brain [38], and the G protein-coupled estrogen receptor (GPER) mainly identified in striatum, hypothalamus, hippocampus, and substantia nigra [39]. ER is encoded by two genes, $\mathrm{ER} \alpha$ and $\mathrm{ER} \beta$, that function both as signal transducers and transcription factors to modulate expression of target-gene [35,40]. The ER $\alpha$ gene (ESR1) is located on chromosome 6q25.1 [41], and the ER $\beta$ (ESR2) gene is located on chromosome 14q22-24 [42]. ER $\alpha$ is mainly expressed in the hypothalamus and amygdala [43,44], areas related to autonomic function, emotional regulation [34], associative learning, and attention [45]. ER $\beta$ is mainly expressed in the hippocampal and entorhinal cortex [46], brain areas related to declarative memory [47,48]. Two of the most studied polymorphisms in the ESR1 gene are PvuII (rs9340799) and Xbal (rs223493) [34,49], which are located in the intron of ESR1 and are in strong linkage disequilibrium with each other [50], which may impact tissue-specific gene expression [51].

Several studies have linked the receptor estrogens alpha and beta with cognitive impairment [34] in diverse populations. The $\mathrm{X}$ and $\mathrm{P}$ alleles of ESR1 have been associated with elevated risk for cognitive impairment in Alzheimer patients and older adults [33,52-55]. The $X$ allele of XbaI polymorphism showed an elevated risk in executive cognitive ability, indicating cognitive impairment in postmenopausal women [56]. The GG genotype of rs9340799 was associated with better immediate recall among African and Caucasian women and rs2234693 CC was associated with better performance on the delayed recall task [57]. Older women with a $\mathrm{p}$ allele had a greater score decline in Mini-Mental State Examination, while women with at least one $x$ allele also had greater score decline [58]. Another study reported that two of the ESR1 SNPs (rs8179176, rs9340799) and two of the ESR2 SNPs (rs1256065, rs1256030) were associated with the likelihood of older women developing cognitive impairment [59]. A recent study found that the XbaI-351 AA genotype was more common 
amongst subjects with cognitive decline, while $-351 \mathrm{G}$ allele carriers showed cognitive stability or improvement [60]. Another study reported that the A allele of rs 1256049 of ESR2 polymorphisms was associated with an increased risk of substantial decline in visual memory, psychomotor speed and on the incidence of Mild Cognitive Impairment [61]. Individuals carrying the minor allele of rs7450824 had a lower risk of Alzheimer disease than homozygous subjects for the major allele [62].

Hence, there is evidence of the influence of estrogen receptors alpha and beta on mood and cognition [34], but their relationship with the processing of emotional faces is not well studied. The goal of the present investigation was to explore the impact of estrogen receptor $\alpha$ and $\beta$ gene polymorphisms on the response to facial emotion recognition tasks that require the identification of emotional expressions by postmenopausal healthy women with low estrogen levels. It was hypothesized that the genetic variants PvuII, Xbal, and rs1256030 of estrogen receptor alpha and estrogen receptor beta confer susceptibility to recognize facial expressions of surprise, anger, happiness, disgust, sadness, and fear emotions.

\section{Materials and Methods}

\subsection{Participants}

Sixty-nine postmenopausal healthy female volunteers between 48 and 60 years old were genotyped for the Xbal, PvuII, and rs1256030 polymorphisms of estrogen receptor genes in a crossover design. The sample size of 69 women with the Xbal polymorphism was calculated to yield an expected power of 0.82 to detect a difference of $10 \%$ on a facial emotion recognition task with a two-sided significance level of $\alpha=0.05$ [63]. The following inclusion criteria were considered: this study assessed a group of females in the postmenopausal period, which is distinguished by a decline of estrogens [28], because it has been found that variations in ovarian hormones modulate emotional processing [22]. In addition, only females were also chosen because they tend to distinguish facial emotions with more accuracy than men [64]. The females intervened a medical examination to evaluate their health condition. To take part in the investigation, females had been amenorrheic for at least 12 months, with no record of cardiovascular, diabetes, metabolic, endocrine or cancer and none of them was on any kind of medication or had ever taken hormones [63]. Initial dementia was excluded employing the Mini-Mental State Examination (MMSE), points of this exam range from 0 to 30, and people with dementia usually score under 24 [65]. In the current investigation, the MMSE scores of the participants ranged from 27 to 30. Major depression was rejected via the Beck Depression Inventory [66], and only females scored between 0 and 9 were incorporated in the study. Each female was evaluated in a unique session by one qualified female researcher during the same time of day (between 09:00 $\mathrm{h}$ and 11:00 h) [63]. In the present study, the visual acuity of the participants was not evaluated by an objectively measured visual acuity to determine visual problems such as glaucoma, macular degeneration or other visual disease that could influence the recognition test. Instead of this procedure, those participants with visual problems were asked to wear glasses with their corrected vision. This investigation was accepted by the Institutional Ethics Committee for Research on Human Subjects and is in accordance with the Declaration of Helsinki [67]. All females gave their written informed consent before enrolling in the investigation.

\subsection{Genotyping}

\subsubsection{ESR1 Gene Polymorphisms}

To detect the ESR1 gene variants, genomic DNA was extracted from peripheral blood leucocytes using High Pure PCR Template Preparation kit (Roche). For the ESR1 Xbal and PvuII polymorphisms, the method previously described by Lui et al. [68] was used. Briefly, a genomic fragment of 1430 bp was amplified by PCR with the primers $5^{\prime}$-CTGCCACCCTATCTGTATCTTTTCCTATTCTCC- $3^{\prime}$ and $5^{\prime}$-TCTTTCTCTGCCACCCTGGCGTCGATTATCTGA-3' ${ }^{\prime}$. The PCR conditions were as follows: 
30 cycles of denaturation $\left(94{ }^{\circ} \mathrm{C}, 30 \mathrm{~s}\right)$, annealing $\left(61^{\circ} \mathrm{C}, 40 \mathrm{~s}\right)$, and extension $\left(72{ }^{\circ} \mathrm{C}, 90 \mathrm{~s}\right)$. After amplification, the products were digested at $37^{\circ} \mathrm{C}$ overnight with either PvuII or Xbal restriction endonucleases, and then electrophoresis was performed in a $1.5 \%$ agarose gel stained with ethidium bromide. To identify the genotypes, lowercase letters ( $\mathrm{p}$ and $\mathrm{x}$ for PvuII and Xbal, respectively) were used to indicate the presence of the restriction site for each endonuclease, and uppercase letters ( $P$ and $X)$ were used to indicate the absence of the restriction sites. Participants were categorized as $\mathrm{PP}$ or $\mathrm{XX}$ homozygotes, $\mathrm{Pp}$ or $\mathrm{Xx}$ heterozygotes and $\mathrm{pp}$ or $\mathrm{xx}$ homozygotes according to the digestion pattern.

\subsubsection{ESR2 Gene Polymorphisms}

The ESR2 polymorphism (rs1256030) was genotyped by sequencing. A genomic fragment of $158 \mathrm{bp}$ was amplified by PCR. For the polymorphism rs1256030 with the primers Forward: 5' GGTAAGATTTGATCTGGCCA $3{ }^{\prime}$ and Reverse: 5' CTGTGGGGAATGACTAATGTT $3^{\prime}$. The PCR conditions were as follows: 35 cycles of denaturation $\left(94^{\circ} \mathrm{C}, 30 \mathrm{~s}\right)$, annealing $\left(63^{\circ} \mathrm{C}, 30 \mathrm{~s}\right)$, and extension $\left(72{ }^{\circ} \mathrm{C}, 30 \mathrm{~s}\right.$ ). The PCR products were purified with columns (Wizard PCR Clean Up system, Promega, Madison, WI, USA). Then, amplified DNA fragments were subjected to direct cycle sequence analysis using the Taq dye-deoxy terminator method and an ABI PRISM 3100 Genetic Analyzer (PE Applied Biosystems, Foster City, CA, USA). The genotypes were classified according to the base identified at position 49 of the $158 \mathrm{bp}$ amplicon. Genotype CC showed a single peak emission for the base fluorescence of $\mathrm{C}$. The TT genotype was recorded when a single peak for T was observed, and the CT genotype was identified by the observation of two different peaks.

\subsection{Facial Emotion Recognition Task}

A computerized task, the Emotion Recognition Task (ERT) [69], was employed to quantify the recognition of six basic facial emotional expressions: anger, disgust, fear, happiness, sadness, and surprise [2]. This task is based on a delayed matching-to-sample paradigm, which requires that a subject learns to give a particular response in the presence of a discriminative or simple stimulus [70,71]. The ERT has been useful to detect variations related to the menstrual cycle and hormones in the processing of emotional faces [24-26] and in amygdala activation during an explicit emotion recognition task [72] in young females. The stimuli employed in the ERT were 26 faces from the 110 Pictures of Facial Affect Series [2], randomly selected to consist of 5 facial expressions of happiness, 4 of surprise, 5 of sadness, 4 of fear, 4 of anger, and 4 of disgust made by female and male actors. The pictures were shown on a screen facing the females with the STIM ${ }^{2}$ cognitive system (NeuroScan), with a program designed for the present study, following the procedure previously described by Gasbarri et al. [24]. The STIM ${ }^{2}$ computer registered the numbers of correct responses, errors, and omissions (when the subjects did not give an answer within $3 \mathrm{~s}$ ) and the response time in $\mathrm{ms}$ (time used to answer) for each emotional face from each participant.

\subsection{Hormone Quantifications}

Following a procedure previously described by Solis-Ortiz et al. [63], a $10 \mathrm{~mL}$ blood sample was extracted from the females. ELISA was employed to quantify $17 \beta$-estradiol and progesterone levels. Commercially available radioimmunoassay kits were employed to quantify luteinizing hormone (LH) and follicle stimulating hormone (FSH) levels. The hormone levels were utilized to verify the hormone condition of the postmenopausal females [73,74].

\subsection{Questionnaires}

\subsubsection{Mood Questionnaire}

Depressive symptoms were evaluated through self-report using the Beck Depression Inventory [66] in a standardized version for the Mexican population [75]. This questionnaire consists 
of 21 items that measure current depressive symptoms. Each item contains a group of four statements, from which the subject chooses one according to how she felt in the last week. Items 1 to 13 assess symptoms that are psychological in nature, while items 14 to 21 assess more physical symptoms. The total score is obtained by adding the scores for the 21 items, with 0 as the lowest score and 64 as the maximum score.

\subsubsection{Mini Mental Test}

The cognitive state of participants was evaluated with The Mini-Mental State Examination (MMSE) [65], which is used to evaluate cognitive function among the elderly. The MMSE includes tests of attention, memory, orientation, language, and visual-spatial skills. Scores on this test range from 0 to 30, and subjects with dementia score below 24 .

\subsection{Statistical Analysis}

Statistical analysis was executed with STATISTICA for Windows 23 (StatSoft, Inc., Tulsa, OK, USA). Following a procedure previously described by Solis-Ortiz et al. [63], the statistical power of the sample [76] was calculated using the Sample Size Calculation and Power Analysis module in STATISTICA. It was employed $\alpha$ (two-tailed) $=0.05$ and $\beta=0.20$ to estimate a standardized effect size of $10 \%$ applying standard methods [77]. Data were examined for a normal distribution using the Kolmogorov-Smirnov test before statistical methods were employed. Descriptive statistics were employed to report the features of the females. All measures from ERT scores were converted to z-scores to compare the values between the ESR1 PvuII P alleles (PP + Pp) and $\mathrm{p}, \mathrm{Xbal} X$ alleles $(\mathrm{XX}+\mathrm{Xx})$ and $\mathrm{x}$, and the ESR2 $\mathrm{C}$ alleles $(\mathrm{CC}+\mathrm{TC})$ vs. TT. This statistical tool produces new variables with a standardized value and describes the location of the value in terms of the standard deviation relative to the mean [78]. A separate Mann-Whitney U test and Student's t-test were computed to compare the $z$-scores from the task between the PvuII P-p, Xbal X-x, and C-T alleles of the ESR1 and ESR2 polymorphisms. The Visual Statistics System (ViSta) for Windows 7.9 module "Effect size" was used to correct the data outliers [63] and estimate the effect sizes [79]. Cohen's d was calculated as the effect size measure and was indicated by the coefficient (d) between allele groups [80]. The coefficient $\mathrm{d}$ values were squared to facilitate interpretation in terms of the percentage of the total variance associated with an effect [63]. Differences were considered significant with alpha levels of $p<0.05$. In the current investigation, it was only examined one specific locus per gene; therefore, it is not required to correct the $p$-value for multiple testing [81].

\section{Results}

\subsection{Features of Females}

Features of the females and the hormonal levels, expressed as the mean and standard deviation, are shown in Table 1. The hormonal levels were within the expected ranges for postmenopausal healthy females [82]. 
Table 1. Women characteristics.

\begin{tabular}{cc}
\hline & $(n=69)$ Mean \pm SD \\
\hline Age (years) & $54.47 \pm 4.70$ \\
Years of education & $10.21 \pm 3.44$ \\
Menarche (years) & $12.86 \pm 1.44$ \\
Menopause (years) & $47.03 \pm 4.85$ \\
Weight $(\mathrm{Kg})$ & $67.37 \pm 13.20$ \\
Height $(\mathrm{cm})$ & $1.56 \pm 0.06$ \\
BMI $\left(\mathrm{Kg} / \mathrm{m}^{2}\right)$ & $27.83 \pm 5.10$ \\
TAS $(\mathrm{mmHg})$ & $105.90 \pm 13.90$ \\
TAD $(\mathrm{mmHg})$ & $77.34 \pm 10.47$ \\
FSH (mlU/mL) & $64.17 \pm 24.90$ \\
LH (mlU/mL) & $31.42 \pm 14.97$ \\
Estradiol $(\mathrm{ng} / \mathrm{mL})$ & $12.45 \pm 2.04$ \\
Progesterone $(\mathrm{ng} / \mathrm{mL})$ & $0.55 \pm 0.11$
\end{tabular}

$\mathrm{BMI}=$ Body Mass Index,$\overline{\mathrm{TAS}}=$ Systolic arterial tension, $\mathrm{TAD}=$ Diastolic arterial tension, $\mathrm{L} H=$ Luteinizing Hormone, $\mathrm{FSH}=$ Stimulating Follicle Hormone.

\subsection{ESR1 Gene Polymorphisms}

\subsubsection{PvuII Polymorphism}

Genetic analysis identified 11 postmenopausal females with the PP genotype (15.94\%), 32 with the Pp genotype (46.38\%), and 26 with the pp genotype (37.68\%), a distribution consistent with Hardy-Weinberg equilibrium $\left(X^{2}=0.048, p=0.82\right)$. To examine the connection between ESR1 polymorphisms and the recognition emotional faces, groups of PP $+\mathrm{Pp}$ genotype carriers were joined into a group denominated the $\mathrm{P}$ allele group to facilitate comparisons with the pp allele group due to the little size of females and to raise the statistical power.

The results of the facial ERT for surprise, anger, happiness, disgust, sadness, and fear scores were transformed from task variables into z-scores for the allele groups $\mathrm{P}$ and $\mathrm{p}$ for the PvuII polymorphism and are shown in Figure 1. As shown in panel a, the response times to recognize facial expressions of surprise $(t=-0.648, p=0.51)$, anger $(t=-0.480, p=0.63)$, happiness $(t=-1.259, p=0.21)$, disgust $(t=-0.527, p=0.59)$, and fear $(t=-0.734, p=0.46)$ were not significantly different between the two allele groups. The response time to recognize sadness was significantly different between the two allele groups $(t=-2.620, p=0.01, d=0.090, p=0.01$, explaining $9.0 \%$ of the entire variance in the data). The z-score demonstrated that females carrying the ESR1 $\mathrm{P}$ allele had a faster response time for recognizing facial expressions of sadness, as indicated by a mean response time $(M=0.45, S D=0.26)$ that was shorter than that of the $\mathrm{p}$ allele group $(\mathrm{M}=1.59, \mathrm{SD}=0.06)$, which had a longer mean response time. Panel $\mathrm{b}$ shows that the recognition accuracy for sadness was significantly different between the two alleles $(t=3.01, p=0.003, \mathrm{~d}=0.109, p=0.006$, explaining $10.9 \%$ of the total variance in the data) and had a large effect size. The z-score indicated that females carrying the ESR1 P allele recognized facial expressions of sadness with better accuracy, as indicated by an accuracy percentage $(\mathrm{M}=0.59, \mathrm{SD}=0.03)$ that was markedly higher than the mean for the ESR1 $\mathrm{p}$ allele group $(\mathrm{M}=-1.53$, $\mathrm{SD}=0.08)$. The recognition accuracy for surprise $(t=-0.118, p=0.90)$, anger $(t=0.421, p=0.67)$, happiness $(t=0.120, p=0.90)$, disgust $(t=-0.501, p=0.61)$, and fear $(t=0.416, p=0.67)$ did not differ significantly between the two allele groups. As shown in panel $c$, the correct responses to recognize surprise $(t=-0.118, p=0.90)$, anger $(t=0.421, p=0.67)$, happiness $(t=0.120, p=0.90)$, disgust $(t=-0.501, p=0.61)$, and fear $(t=0.416, p=0.67)$ were not significantly different between the two allele groups. The numbers of correct responses in recognizing sadness were significantly different between the two alleles $(t=3.016, p=0.003, d=0.109, p=0.006$, explaining $10.9 \%$ of the total variance in the data). The z-score demonstrated that females carrying the ESR1 P allele produced more correct responses for recognizing facial expressions of sadness, as indicated by a larger mean number of correct responses $(\mathrm{M}=1.10, \mathrm{SD}=0.05)$ than in the ESR1 $\mathrm{p}$ allele group $(\mathrm{M}=0.01, \mathrm{SD}=0.02)$. As shown 
in panel $\mathrm{d}$, the numbers of omissions in response to surprise $(t=-0.155, p=0.87)$, anger $(t=-1.585$, $p=0.11)$, happiness $(t=-1.175, p=0.24)$, disgust $(t=1.233, p=0.22)$, and fear $(t=-0.726, p=0.47)$ were not significantly different between the two allele groups. The numbers of omissions in response to faces showing sadness were significantly different between the two allele groups $(t=-3.393, p=0.001$, $\mathrm{d}=0.136, p=0.002$, explaining $13.6 \%$ of the total variance in the data). The $\mathrm{z}$-score demonstrated that females carrying the ESR1 P allele omitted fewer responses when shown facial expressions of sadness, as indicated by a lower mean number of omissions $(\mathrm{M}=-0.14, \mathrm{SD}=0.02)$ than for the ESR1 $\mathrm{p}$ allele group $(\mathrm{M}=1.70, \mathrm{SD}=0.06)$. The errors committed in recognizing facial expressions of surprise $(\mathrm{U}=555, p=0.93)$, anger $(\mathrm{U}=461, p=0.14)$, happiness $(\mathrm{U}=520, p=0.49)$, disgust $(\mathrm{U}=545.5, p=0.90)$, fear $(\mathrm{U}=532, p=0.73)$, and sadness $(\mathrm{U}=508, p=0.38)$ were not considerably distinctive between the two allele groups.
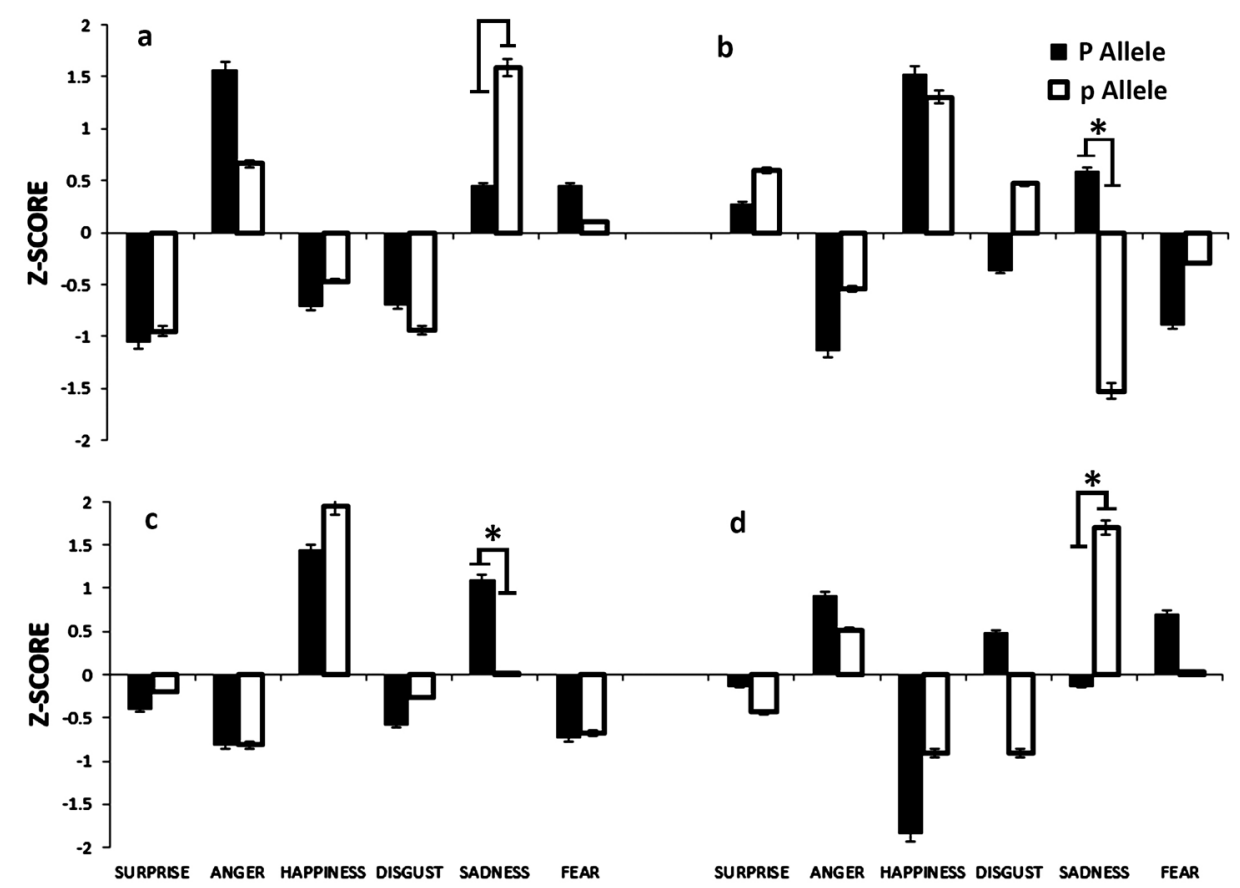

Figure 1. Shows the $z$-scores of the facial emotion recognition task for the two allele groups ESR1 P and $\mathrm{p}$ of the PvuII polymorphism. The panels show response time (a), accuracy (b), correct responses (c), and omissions (d). Asterisks indicate significant differences between the allele groups $\left({ }^{*} p<0.05\right)$.

\subsubsection{Xbal Polymorphism}

Genetic analysis identified 5 females with the XX (7.35\%) genotype, 34 with the Xx genotype $(50.00 \%)$, and 29 with the $x x$ genotype $(42.65 \%)$, a distribution consistent with Hardy-Weinberg equilibrium $\left(X^{2}=1.37, p=0.24\right)$. To examine the connection between ESR1 polymorphisms and the recognition of emotional faces, groups of $X X+X x$ genotype carriers were joined into a group denominated the $\mathrm{X}$ allele group to facilitate comparisons with the $\mathrm{xx}$ allele group due to the little size of females and to raise statistical power.

The results of the facial emotion recognition task, given as the scores for surprise, anger, happiness, disgust, sadness, and fear from the variable task, were transformed to z-scores for the two allele groups ESR1 $\mathrm{X}$ and ESR1 $\mathrm{x}$ for the Xbal polymorphism and are shown in Figure 2. As shown in panel a, the response times for recognizing surprise $(U=553, p=0.88)$, anger $(U=493.5, p=0.37)$, happiness $(\mathrm{U}=506.5, p=0.46)$, disgust $(\mathrm{U}=537, p=0.73)$, and fear $(\mathrm{U}=514, p=0.53)$ were not significantly different between the two allele groups. The response time for recognizing sadness was significantly different between the two alleles ( $\mathrm{U}=439, p=0.05, \mathrm{~d}=0.043, p=0.08$, explaining $4.30 \%$ of the total variance in the data). The $z$-score demonstrated that women carrying the ESR $1 \mathrm{X}$ allele had a faster response time for facial expressions of sadness, as indicated by a mean response time $(M=0.33$, 
$\mathrm{SD}=0.05)$ shorter than that for the ESR1 $\mathrm{x}$ allele group $(\mathrm{M}=1.61, \mathrm{SD}=0.10)$. In panel $\mathrm{b}$, the recognition accuracy for surprise $(U=508.5, p=0.39)$, anger $(U=440.5, p=0.08)$, happiness $(U=498.5, p=0.30)$, and disgust $(\mathrm{U}=455.0, p=0.12)$ were not significantly different between the two allele groups. However, the recognition accuracy for sadness was significantly different between the two allele groups ( $\mathrm{U}=414.5, p=0.03, \mathrm{~d}=0.053, p=0.05$, explaining $5.3 \%$ of the total variance in the data). The z-score demonstrated that females carrying the ESR1 $\mathrm{X}$ allele recognized the facial expressions of sadness more accurately, as indicated by a mean accuracy $(\mathrm{M}=0.48, \mathrm{SD}=0.02)$ higher than that of the ESR1 $\mathrm{x}$ allele group $(\mathrm{M}=-1.88, \mathrm{SD}=0.15)$. The recognition accuracy for fear was also significantly different between the two alleles $(\mathrm{U}=405.5, p=0.03, \mathrm{~d}=0.057, p=0.05$, explaining $5.7 \%$ of the total variance in the data). The z-score demonstrated that women carrying the ESR1 X allele recognized the facial expressions of fear with lower accuracy, as indicated by a mean accuracy $(\mathrm{M}=-1.01, \mathrm{SD}=0.10)$ lower than that of the ESR1 $\mathrm{x}$ allele group $(\mathrm{M}=0.21, \mathrm{SD}=0.02)$. As shown in panel $\mathrm{c}$, the numbers of correct responses for recognizing surprise $(U=508.5, p=0.39)$, anger $(U=440.5, p=0.09)$, happiness ( $\mathrm{U}=498.5, p=0.30)$ and disgust $(\mathrm{U}=455, p=0.12)$ were not significantly different between the two allele groups. The correct responses for recognizing sadness were significantly different between the two alleles ( $\mathrm{U}=414.5, p=0.03, \mathrm{~d}=0.053, p=0.05$, explaining $5.3 \%$ of the total variance in the data). The z-score demonstrated that women carrying the ESR1 $\mathrm{X}$ allele were better able to recognize facial expressions of sadness, as indicated by a higher mean number of correct responses $(\mathrm{M}=0.99, \mathrm{SD}=0.07)$ than in the ESR1 $x$ allele group $(\mathrm{M}=0.20, \mathrm{SD}=0.01)$. The numbers of correct responses for recognizing fear were also significantly different between the two alleles $(\mathrm{U}=405.5, p=0.03, \mathrm{~d}=0.057, p=0.05$, explaining $5.7 \%$ of the total variance in the data). The z-score demonstrated that women carrying the ESR1 $\mathrm{X}$ allele had fewer correct responses for recognizing facial expressions of fear, as indicated by a lower mean number of correct responses $(\mathrm{M}=-0.81, \mathrm{SD}=0.04)$ than in the ESR1 $\mathrm{x}$ allele group $(\mathrm{M}=-0.55, \mathrm{SD}=0.02)$. As shown in panel $\mathrm{d}$, the omissions when recognizing the emotions surprise $(\mathrm{U}=549, p=0.79)$, anger $(\mathrm{U}=516, p=0.49)$, happiness $(\mathrm{U}=565, p=0.99)$, and fear $(\mathrm{U}=536.5, p=0.64)$ were not significantly different between the two allele groups. The omissions in response to disgust were significantly different between the two allele groups $(U=445.5, p=0.05, d=0.068, p=0.03$, explaining $6.8 \%$ of the total variance in the data). The z-score demonstrated that women carrying the ESR1 $\mathrm{X}$ allele omitted more responses to facial expressions of sadness, as indicated by a higher mean number of omissions $(\mathrm{M}=0.27, \mathrm{SD}=0.01)$ than that for the $E S R 1 \times$ allele group $(\mathrm{M}=-0.82, \mathrm{SD}=0.05)$. The numbers of omissions when recognizing sadness were also significantly different between the two alleles ( $\mathrm{U}=386.5, p=0.006, \mathrm{~d}=0.095, p=0.01$, explaining $9.5 \%$ of the total variance in the data). The $z$-score demonstrated that women carrying the ESR1 $\mathrm{X}$ allele omitted fewer responses to facial expressions of sadness, as indicated by a lower mean number of omissions $(\mathrm{M}=-0.38, \mathrm{SD}=0.01)$ than in the ESR1 $\mathrm{x}$ allele group $(\mathrm{M}=1.88, \mathrm{SD}=0.10)$. There were no significant differences between the two allele groups in the numbers of errors made during recognition of facial expressions of surprise $(\mathrm{U}=519.5, p=0.39)$, anger $(\mathrm{U}=472, p=0.15)$, happiness $(\mathrm{U}=486.5, p=0.16)$, disgust $(\mathrm{U}=544.5$, $p=0.71)$, fear $(\mathrm{U}=467, p=0.12)$ and sadness $(\mathrm{U}=564, p=0.98)$. 


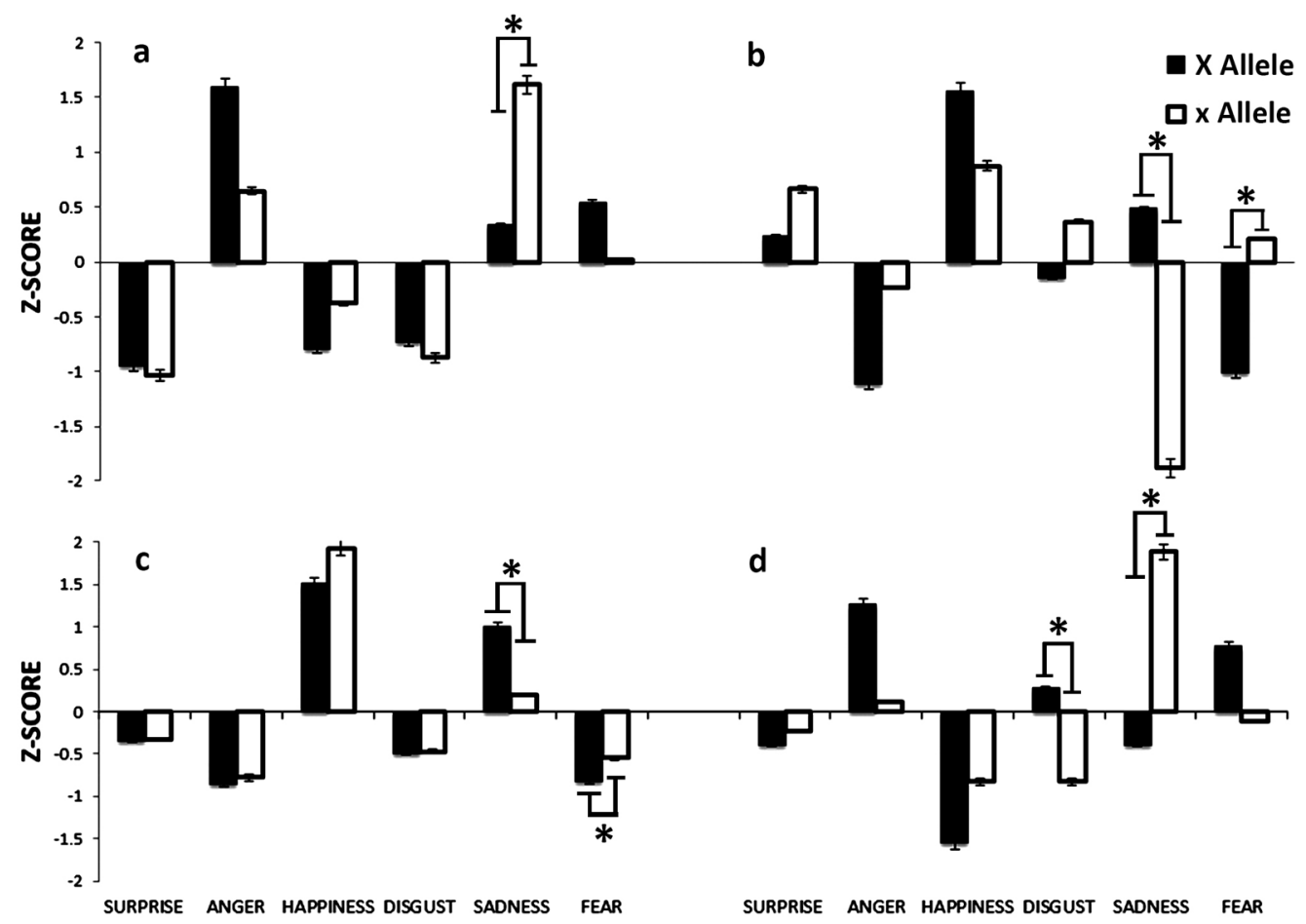

Figure 2. Shows the $z$-scores of the facial emotion recognition task for the two allele groups ESR $1 \mathrm{X}$ and $\mathrm{x}$ of the Xbal polymorphism. The panels show response time (a), accuracy (b), correct responses (c), and omissions (d). Asterisks indicate significant differences between the allele groups $\left({ }^{*} p<0.05\right)$.

\subsection{ESR2 rs1256030 Polymorphism}

Genetic analysis identified 17 females with the CC (27.42\%) genotype, 33 with the CT genotype (53.23\%), and 12 with the TT genotype (19.35\%), a distribution consistent with Hardy-Weinberg equilibrium $\left(X^{2}=3.16, p=0.57\right)$. To examine the connection between ESR2 polymorphisms and the recognition of emotional faces, groups of $\mathrm{CC}+\mathrm{CT}$ genotype carriers were joined in a group denominated the $C$ allele group to facilitate comparisons with the TT allele group due to the little size of females and to raise the statistical power.

The results of the facial emotion recognition task for surprise, anger, happiness, disgust, sadness, and fear scores were transformed from task variables into z-scores for the two allele groups, ESR2 C and ESR2 T, for the ESR2 (rs1256030) polymorphism and are shown in Table 2. The response time to recognize facial expressions of surprise $(\mathrm{U}=161.5, \mathrm{~d}=0.067, p=0.03$, explaining $6.7 \%$ of the total variance in the data) and anger $(\mathrm{U}=155.0, \mathrm{~d}=0.093, p=0.02$, explaining $9.3 \%$ of the total variance in the data) were significantly different between the two alleles. The z-score demonstrated that women carrying the ESR2 $\mathrm{T}$ allele showed slower response times for recognizing facial expressions of surprise $(\mathrm{M}=-1.61, \mathrm{SD}=0.08)$, as indicated by a shorter-than-average response time. Women carrying the ESR2 C allele showed a faster response time for recognizing facial expressions of anger $(\mathrm{M}=1.37$, $\mathrm{SD}=0.05)$, as indicated by a longer-than-average response time. There were no significant differences between the two allele groups regarding accuracy, correct responses, omission, and errors when recognizing facial expressions of surprise, anger, happiness, disgust, sadness, and fear. 
Table 2. Results of the facial emotion recognition task scores transformed from task variables into z-scores for the two allele groups, ESR2 C and ESR2 T, for the ESR2 (rs1256030) polymorphism.

\begin{tabular}{|c|c|c|c|c|c|}
\hline & C Allele Mean \pm SD & $\mathrm{T}$ Allele Mean $\pm \mathrm{SD}$ & U Value & Cohen's d & $p$ \\
\hline \multicolumn{6}{|c|}{ Response Time } \\
\hline Surprise & $-1.15 \pm 0.08$ & $-1.61 \pm 0.09$ & 161.5 & 0.067 & $0.03 *$ \\
\hline Anger & $1.37 \pm 0.05$ & $0.24 \pm 0.01$ & 155.0 & 0.093 & $0.02 *$ \\
\hline Happiness & $-0.47 \pm 0.03$ & $-0.49 \pm 0.02$ & 186.5 & 0.046 & 0.11 \\
\hline Disgust & $-0.86 \pm 0.04$ & $-0.10 \pm 0.01$ & 248.0 & 0.005 & 0.69 \\
\hline Sadness & $0.85 \pm 0.04$ & $1.24 \pm 0.05$ & 255.0 & 0.005 & 0.79 \\
\hline Fear & $0.25 \pm 0.02$ & $0.73 \pm 0.03$ & 244.0 & 0.005 & 0.63 \\
\hline \multicolumn{6}{|l|}{ Accuracy } \\
\hline Surprise & $0.77 \pm 0.03$ & $1.01 \pm 0.03$ & 262.5 & 0.002 & 0.99 \\
\hline Anger & $-1.39 \pm 0.05$ & $-0.30 \pm 0.01$ & 209.5 & 0.023 & 0.23 \\
\hline Happiness & $1.32 \pm 0.05$ & $1.40 \pm 0.03$ & 251.5 & 0.001 & 0.72 \\
\hline Disgust & $0.34 \pm 0.02$ & $-0.96 \pm 0.03$ & 261.0 & 0.005 & 0.88 \\
\hline Sadness & $-0.41 \pm 0.02$ & $-0.17 \pm 0.01$ & 257.0 & 0.004 & 0.79 \\
\hline Fear & $-0.63 \pm 0.02$ & $-0.96 \pm 0.03$ & 261.5 & 0.001 & 0.85 \\
\hline \multicolumn{6}{|c|}{ Correct Responses } \\
\hline Surprise & $-0.27 \pm 0.04$ & $-0.29 \pm 0.01$ & 262.5 & 0.002 & 0.99 \\
\hline Anger & $-0.99 \pm 0.10$ & $-0.62 \pm 0.05$ & 209.5 & 0.023 & 0.23 \\
\hline Happiness & $1.57 \pm 0.15$ & $1.49 \pm 0.15$ & 251.5 & 0.001 & 0.72 \\
\hline Disgust & $-0.41 \pm 0.05$ & $-0.79 \pm 0.05$ & 261.0 & 0.005 & 0.88 \\
\hline Sadness & $0.85 \pm 0.08$ & $1.00 \pm 0.07$ & 257.0 & 0.004 & 0.79 \\
\hline Fear & $-0.74 \pm 0.08$ & $-0.79 \pm 0.05$ & 261.5 & 0.001 & 0.85 \\
\hline \multicolumn{6}{|l|}{ Errors } \\
\hline Surprise & $-1.62 \pm 0.10$ & $-1.11 \pm 0.05$ & 266.0 & 0.001 & 0.93 \\
\hline Anger & $1.03 \pm 0.05$ & $1.11 \pm 0.04$ & 258.5 & 0.001 & 1.00 \\
\hline Happiness & $-0.29 \pm 0.02$ & $1.11 \pm 0.03$ & 257.5 & 0.005 & 0.86 \\
\hline Disgust & $0.14 \pm 0.01$ & $-1.11 \pm 0.03$ & 239.0 & 0.013 & 0.45 \\
\hline Sadness & $-0.29 \pm 0.02$ & $0.18 \pm 0.01$ & 253.5 & 0.001 & 0.68 \\
\hline Fear & $1.03 \pm 0.04$ & $0.18 \pm 0.01$ & 261.5 & 0.002 & 0.89 \\
\hline \multicolumn{6}{|l|}{ Omissions } \\
\hline Surprise & $-0.63 \pm 0.05$ & $-0.45 \pm 0.02$ & 266.5 & 0.001 & 1.00 \\
\hline Anger & $1.07 \pm 0.10$ & $-0.45 \pm 0.02$ & 209.0 & 0.034 & 0.20 \\
\hline Happiness & $-1.24 \pm 0.10$ & $-1.54 \pm 0.13$ & 236.5 & 0.025 & 0.34 \\
\hline Disgust & $-0.63 \pm 0.05$ & $1.18 \pm 0.07$ & 220.5 & 0.027 & 0.19 \\
\hline Sadness & $1.20 \pm 0.10$ & $0.63 \pm 0.03$ & 252.0 & 0.006 & 0.70 \\
\hline Fear & $0.22 \pm 0.02$ & $0.63 \pm 0.03$ & 245.5 & 0.001 & 0.64 \\
\hline
\end{tabular}

\section{Discussion}

The findings of the current investigation demonstrated significant effects of the genetic variants PvuII and Xbal of the polymorphic genes ESR1 and ESR2 on facial emotion recognition ability in postmenopausal females. Our outcome displayed that the recognition of facial expression of sadness is modulated by ESR1 gene polymorphisms. Females carrying the ESR1 P allele of the PvuII polymorphism recognized facial expressions of sadness more easily than the women carrying the ESR1 $\mathrm{p}$ allele, as indicated by their higher accuracy, faster response time, greater numbers of correct responses, and fewer omissions on the facial emotional recognition task. This result explained $10.9 \%$, $9.0 \%, 10.9 \%$, and $13.6 \%$ of the entire variance, respectively, and it also showed a large effect size. Similarly, women carrying the ESR1 X allele of the Xbal polymorphism were better able to recognize the facial expressions of sadness than the women carrying the ESR1 $\mathrm{x}$ allele, as indicated by the higher accuracy, fast response time, more response corrects, and fewer omissions committed on the facial emotional recognition task. This outcome explained $5.3 \%, 4.3 \%, 5.3 \%$, and $6.8 \%$ of the total variance, respectively, and it also showed a medium effect size. Interestingly, no effect of the ESR1 gene 
polymorphisms was found on recognition of the facial expressions of surprise, anger, and happiness. The ESR2 only showed a significant effect in the response time to recognize facial expressions of surprise and anger.

The identification of facial expressions of sadness by postmenopausal females carrying ESR1 and ESR2 gene polymorphisms found in the present study suggests an effect of the expression of estrogen receptors on emotion processing. However, previous studies reported in the literature relating to estrogen receptors and emotion recognition are scarce. One study reported that females carrying rare alleles of the three ESR2 SNPs, rs928554, rs1271572, and rs1256030, which are in linkage disequilibrium with each other, displayed superior face recognition compared with noncarriers in a face memory task, and suggested that estrogen receptors may regulate social memory functions in humans [1]. Coincidentally, our results based on the facial emotional recognition task found that postmenopausal females carrying the ESR2 C allele showed a faster response time for recognizing facial expressions of anger, as indicated by a response time shorter than the mean for females carrying the ESR2 $\mathrm{T}$ allele. In addition, there is evidence that ESR2 are linked to anxiety disorders and can act as modulators of anxiety-like behavior [83]. An investigation noted that, for the ER $\beta$ gene ESR2, the SNP rs1256049 was related with a greater incidence of generalized anxiety disorder in older women [84], while the female ER $\beta$ knockout mice increased anxiety-like behaviors [85]. A study analyzed the anxious behavior resulting from the deletion of genes involved in anxiety to their brain expression in mice, with one of them being the ESR2 gene [86]. This study found that the genes accompanied, after deletion, by a modification of the anxious behavior, have lower expression in the cerebral cortex, the amygdala and the ventral striatum, brain regions involved in the emotional circuit, and that presynaptic genes are involved in the emergence of anxiety and postsynaptic genes in the reduction of anxiety after gene deletion. [86]. In addition, it has been described that ESR1 are also involved in the motivational system [87], and that a hypertrophy of mesocorticolimbic system is associated with increased activity and impaired attention of Naples high excitability rats [88].

Some studies conducted in young females have linked the facial expression of emotion with variations in sex hormones during the menstrual cycle [22]. Although these studies did not analyze estrogen receptors, they support the results found in the present study. Better emotion recognition accuracy for sad faces has been reported in the early follicular phase, which is distinguished by low levels of estrogen [25]. Another study reported working memory deficits for sad and disgusted faces in the early follicular phase, which is related to low estrogen and progesterone levels, compared with the luteal phase of the menstrual cycle in healthy women [24]. Better emotion recognition accuracy was reported in the early follicular phase in healthy young women [89]. These outcomes are partially consistent with our results because postmenopause is also distinguished by low levels of serum estrogens. Moreover, our research found better facial sadness recognition related to certain estrogen receptor ESR1 gene polymorphisms. It is not known how this variant could influence estrogen signaling and to affect the recognition of sad expressions. It is likely that the Xbal and PvuII SNPs as well as the TA-repeat do not affect estrogen signaling but may be in linkage disequilibrium with other yet-unidentified causative functional variant in the ESR1 gene [34,50,90].

The ERT employed in the current investigation requires the use of working memory, which implies to the mechanisms that are considered to be essential in order to keep things in mind while executing complex tasks such as reasoning, understanding, and learning [91]. Working memory is modulated by the prefrontal cortex [92], where estrogen receptors have been found [93], indicating that estrogen may affect prefrontal functions [94]. Furthermore, estrogens increase the levels of neurotransmitters, promote neuronal growth and synapse formation, and regulate second messenger systems $[95,96]$. Thus, a decrease in estrogen, which occurs during postmenopause, could be detrimental to working memory processes in prefrontal function [97]. A previous study reported that executive function was lower in late postmenopause than the women in the early postmenopausal stage, while there were no changes in other cognitive domains [97]. Associative memory and episodic verbal memory performance were worse in postmenopausal women, suggesting deficits in executive functions $[98,99]$. 
In the current investigation, it was remarkable to note that postmenopausal females carrying the $\mathrm{P}$ allele of the PvuII polymorphism or the X allele of the Xbal polymorphism of ESR1 displayed higher accuracy, fast response time, more correct responses, and fewer omissions to complete the task, with a large effect size. These results suggest that ER alpha maintains transcription and memory as estradiol levels decline [100], facilitating the execution of the task in healthy females.

It is also significant to remark that the postmenopausal females examined in the current investigation were in good health without any evident record of diagnosis of major depression or cognitive alterations, which were detected by self-report questionnaires. Nevertheless, the results of the current investigation demonstrate that females carrying the $\mathrm{P}$ allele of PvuII and the $\mathrm{X}$ allele of Xbal, two polymorphisms of ESR1, displayed better accuracy in the recognition of sad expressions, which could reflect a subtle propensity for depression during the postmenopausal period. Some studies have considered the possibility that vision impairment is related to symptoms of anxiety and depression in the elderly [101], although the present study did not measure the visual acuity of postmenopausal females with a vision test. Evidence suggests that including a measurement for visual impairment may be relevant. For instance, one study found that in a sample of young and middle-aged U.S. adults with worse visual function displayed increased odds of having an anxiety disorder [102]. Another study which carried out a systematic review found that depression was associated with visual impairment, although the studies considered in the review lacked a standardized evaluation of visual acuity, which makes it difficult to establish a reliable association with the depressive symptoms [103]. Thus, future studies should consider measuring visual impairments in emotional processing.

Several studies have suggested that ESR1 has a role in depression $[34,104]$. These receptors are mainly expressed in the hypothalamus and amygdala $[43,44,105]$, areas related in autonomic function and emotional regulation $[34,106]$. Genetic variation in the estrogen receptors may modify estrogen signaling, thus influencing a woman's susceptibility to developing depression [107]. A study conducted on Chinese women diagnosed with major depression and healthy controls found that women carrying the genotype PP of the PvuII SNP had a higher risk of major depression compared to women with the Pp or pp genotype [108]. Women homozygous for the variant $\mathrm{X}$ allele of ESR1 rs9340799 had an increased risk of diagnosis for major depression across their lifetime compared with women who were homozygous for the $\mathrm{x}$ allele, while the XX genotype of rs9340799 was specifically associated with an increased risk of recurrent depressive episodes [104]. Women carrying the AA alleles in the ESR1 polymorphism rs9340799 had an increased lifetime prevalence of major depression among postmenopausal female users of hormonal therapy [109]. Another study conducted in postmenopausal females found that the ESR1 454(-351) AG and 454(-351) AG + GG genotypes were related with lower risk of depression [110]. Moreover, it was also reported that females with the AA alleles of ESR2 rs4986938 had a higher lifetime prevalence of major depression than women with GA and GG genotypes [109].

The molecular mechanisms by which these polymorphisms alter the activity of the receptor are not clear, since PvuII and Xbal are located in an intronic and apparently nonfunctional region of the gene [50]. Potential reasons comprehend the existence of functional combinations among polymorphic alleles wherein two markers in blend would modify the genetic function as well as the stability of the RNA [111]. Another reason would be that polymorphisms in the intron could be in linkage disequilibrium with the exon, which would affect the function of the estrogen receptor [112].

Moreover, there is evidence linking variations in estrogen levels with susceptibility to depression, particularly in females during postmenopause [113-115], which is distinguished by low serum estrogens [28], consistent with the findings of the current study. Estrogen modulates serotonergic function [116-119], which has been correlated to several aspects of mood and emotional information processing [120]. Some studies that employed a facial emotion recognition task showed that patients with a diagnosis of major depression tend to be better at identifying negative stimuli, such as sad faces [121], and to show increased vigilance and selective attention towards sad expressions [122], that women with depression in remission correctly identified more emotions as anger, fear, and sadness 
than controls [123] and that patients with depression had a higher accuracy rate for recognition of sadness compared to controls [124].

The administration of hormone replacement therapy has been used to examine the effects during emotional processing in females. For example, a study revealed that postmenopausal women treated with estrogens showed higher activation than women without estrogens treatment in the entorhinal cortex during processing of negative pictures, whereas women who used estrogens recently showed greater activation in the hippocampus and higher emotion recognition accuracy of neutral stimuli [125]. Another study reported that postmenopausal women treated with estrogen plus progesterone showed activation in the orbital, frontal, cingulate, and occipital cortices during processing of negative emotional pictures [126]. Moreover, it was observed that the administration of raloxifene, a selective estrogen receptor modulator, binds estrogen receptor alpha (ESR- $\alpha$ ) [127], increased PFC activity during inhibition of response to negative words and was greater in patients with schizophrenia homozygous for ESR1 rs9340799 AA relative to G carriers [128].

There are some limitations that must be considered in the present study. This study was conducted in a specific sample of Mexican postmenopausal women with low estrogen levels. The study did not include females with high estrogen levels, which must be included in future approaches to determine whether there are differences associated with the estrogen receptors. It also must include the analysis of other polymorphisms associated with estrogen and serotonin metabolisms. Other studies must include individuals of different ages and gender to consider sex differences in the mood and cognition.

The findings of the present study have some implications for the clinical practice. Women in early postmenopause may be prone to depression, because they are carriers of a variant of the estrogen receptor that confers risk to depression. This could have important preventive and therapeutic implications, to develop specific medicines based on the genetic profile of people with depression, especially in those people who do not respond to conventional treatment.

\section{Conclusions}

The actual outcomes add novel details about the impact of estrogen receptors on facial emotion recognition in postmenopausal healthy females with reduced estrogen levels. The outcomes of the current investigation show better recognition of the facial expression of sadness by carriers of the $P$ allele and the $\mathrm{X}$ allele of ESR1 and ESR2 gene polymorphisms, but no such differences were found for facial expressions of happiness. These findings suggest that emotional processing displays contrasts depending on the estrogen receptor gene variants, which in part describes individual contrasts in the identification of facial aspect of sadness manifested by postmenopausal healthy females.

Author Contributions: S.S.-O. conceived, planned, and executed the research, examined the data, and wrote the paper. M.E.F.-A. carried out the molecular genetic analysis. M.G.-M. executed the investigation, data analysis and realized the molecular genetic analysis. V.E.A.-A. carried out the molecular genetic analysis. E.G.G.-P. analyzed the information and designed the figures. All authors have read and approved the final paper.

Funding: This research was funded by the University of Guanajuato, Campus León. Mayra L. Gutiérrez-Muñoz received a CONACYT scholarship (Number 33738) for work on her doctoral degree.

Acknowledgments: This study won the award for the First Place in Basic Science during the XXVII National Congress of Research in Medicine, October 2013 in Monterrey, Nuevo Léon, México.

Conflicts of Interest: The authors declare no conflicts of interest.

\section{References}

1. Karlsson, S.; Henningsson, S.; Hovey, D.; Zettergren, A.; Jonsson, L.; Cortes, D.S.; Melke, J.; Laukka, P.; Fischer, H.; Westberg, L. Social memory associated with estrogen receptor polymorphisms in women. Soc. Cogn. Affect. Neurosci. 2016, 11, 877-883. [CrossRef] [PubMed]

2. Ekman, P.; Friesen, W.V. Pictures of Facial Affect; Consulting Psychologist Press: Palo Alto, CA, USA, 1976.

3. Phelps, E.A. Human emotion and memory: Interactions of the amygdala and hippocampal complex. Curr. Opin. Neurobiol. 2004, 14, 198-202. [CrossRef] [PubMed] 
4. Virtanen, M.; Singh-Manoux, A.; Batty, G.D.; Ebmeier, K.P.; Jokela, M.; Harmer, C.J.; Kivimäki, M. The level of cognitive function and recognition of emotions in older adults. PLoS ONE 2017, 12, e0185513. [CrossRef] [PubMed]

5. Davis, M.; Whalen, P.J. The amygdala: Vigilance and emotion. Mol. Psychiatry 2001, 6, 13-34. [CrossRef] [PubMed]

6. Phelps, E.A.; LeDoux, J.E. Contributions of the amygdala to emotion processing: From animal models to human behavior. Neuron 2005, 48, 175-187. [CrossRef] [PubMed]

7. Calder, A.J.; Lawrence, A.D.; Young, A.W. The neuropsychology of fear and loathing. Nat. Rev. Neurosci. 2001, 2, 352-363. [CrossRef] [PubMed]

8. Morris, J.S.; Frith, C.D.; Perrett, D.I.; Rowland, D.; Young, A.W.; Calder, A.J.; Dolan, R.J. A differential neural response in the human amygdala to fearful and happy facial expressions. Nature 1996, 383, 812-815. [CrossRef] [PubMed]

9. Zhao, K.; Zhao, J.; Zhang, M.; Cui, Q.; Fu, X. Neural responses to rapid facial expressions of fear and surprise. Front. Psychol. 2017, 8, 761. [CrossRef] [PubMed]

10. Phillips, M.L.; Young, A.W.; Senior, C.; Brammer, M.; Andrew, C.; Calder, A.J.; Bullmore, E.T.; Perrett, D.I.; Rowland, D.; Williams, S.C.; et al. A specific neural substrate for perceiving facial expressions of disgust. Nature 1997, 389, 495-498. [CrossRef] [PubMed]

11. Suzuki, A. Insula and disgust. Rinsho Shinkeigaku 2010, 50, 1000-1002. [CrossRef] [PubMed]

12. Thompson, A.E.; Voyer, D. Sex differences in the ability to recognise non-verbal displays of emotion: A meta-analysis. Cogn. Emot. 2014, 28, 1164-1195. [CrossRef] [PubMed]

13. Hall, J.A.; Matsumoto, D. Gender differences in judgments of multiple emotions from facial expressions. Emotion 2004, 4, 201-206. [CrossRef] [PubMed]

14. Sawada, R.; Sato, W.; Kochiyama, T.; Uono, S.; Kubota, Y.; Yoshimura, S.; Toichi, M. Sex differences in the rapid detection of emotional facial expressions. PLoS ONE 2014, 9, e94747. [CrossRef] [PubMed]

15. Sadeh, N.; Javdani, S.; Finy, M.S.; Verona, E. Gender differences in emotional risk for self- and other-directed violence among externalizing adults. J. Consult. Clin. Psychol. 2011, 79, 106-117. [CrossRef] [PubMed]

16. Iliceto, P.; Pompili, M.; Lester, D.; Gonda, X.; Niolu, C.; Girardi, N.; Rihmer, Z.; Candilera, G.; Girardi, P. Relationship between temperament, depression, anxiety, and hopelessness in adolescents: A structural equation model. Depress. Res. Treat. 2011, 2011, 160175. [CrossRef] [PubMed]

17. Dadomo, H.; Grecucci, A.; Giardini, I.; Ugolini, E.; Carmelita, A.; Panzeri, M. Schema therapy for emotional dysregulation: Theoretical implication and clinical applications. Front. Psychol. 2016, 7, 1987. [CrossRef] [PubMed]

18. Perry, L.M.; Goldstein-Piekarski, A.N.; Williams, L.M. Sex differences modulating serotonergic polymorphisms implicated in the mechanistic pathways of risk for depression and related disorders. J. Neurosci. Res. 2017, 95, 737-762. [CrossRef] [PubMed]

19. Slopién, R.; Slopién, A.; Rozycka, A.; Warenik-Szymankiewicz, A.; Lianeri, M.; Jagodzinski, P.P. The c.1460C $>\mathrm{T}$ polymorphism of MAO-A is associated with the risk of depression in postmenopausal women. Sci. World J. 2012, 2012, 194845. [CrossRef]

20. Serafini, G.; Pompili, M.; Innamorati, M.; Gentile, G.; Borro, M.; Lamis, D.A.; Lala, N.; Negro, A.; Simmaco, M.; Girardi, P.; et al. Gene variants with suicidal risk in a sample of subjects with chronic migraine and affective temperamental dysregulation. Eur. Rev. Med. Pharmacol. Sci. 2012, 16, 1389-1398.

21. Little, A.C. The influence of steroid sex hormones on the cognitive and emotional processing of visual stimuli in humans. Front. Neuroendocrinol. 2013, 34, 315-328. [CrossRef]

22. Osório, F.L.; de Paula Cassis, J.M.; Machado de Sousa, J.P.; Poli-Neto, O.; Martín-Santos, R. Sex hormones and processing of facial expressions of emotion: A Systematic literature review. Front. Psychol. 2018, 9, 529. [CrossRef] [PubMed]

23. Pearson, R.; Lewis, M.B. Fear recognition across the menstrual cycle. Horm. Behav. 2005, 47, $267-271$. [CrossRef] [PubMed]

24. Gasbarri, A.; Pompili, A.; d'Onofrio, A.; Cifariello, A.; Tavares, M.C.; Tomaz, C. Working memory for emotional facial expressions: Role of the estrogen in young women. Psychoneuroendocrinology 2008, 33, 964-972. [CrossRef] 
25. Guapo, V.G.; Graeff, F.G.; Zani, A.C.; Labate, C.M.; dos Reis, R.M.; Del-Ben, C.M. Effects of sex hormones levels and phases of the menstrual cycle in the processing of emotional faces. Psychoneuroendocrinology 2009, 34, 1087-1094. [CrossRef] [PubMed]

26. Kamboj, S.K.; Krol, K.M.; Curran, H.V. A specific association between facial disgust recognition and estradiol levels in naturally cycling women. PLoS ONE 2016, 10, e0122311. [CrossRef] [PubMed]

27. Dalal, K.; Agarwal, M. Postmenopausal syndrome. Indian J. Psychiatry 2015, 57, S222-S232. [CrossRef] [PubMed]

28. Santoro, N.; Epperson, C.N.; Mathews, S.B. Menopausal symptoms and their management. Endocrinol. Metab. Clin. N. Am. 2015, 44, 497-515. [CrossRef]

29. Halbreich, U. Role of estrogen in postmenopausal depression. Neurology 1997, 48, 16-19. [CrossRef]

30. Freeman, E.W.; Sammel, M.D.; Liu, L.; Gracia, C.R.; Nelson, D.B.; Hollander, L. Hormones and menopausal status as predictors of depression in women in transition to menopause. Arch. Gen. Psychiatry 2004, 61, 62-70. [CrossRef]

31. Núñez-Pizarro, J.L.; González-Luna, A.; Mezones-Holguín, E.; Blümel, J.E.; Barón, G.; Bencosme, A.; Benítez, Z.; Bravo, L.M.; Calle, A.; Flores, D.; et al. Association between anxiety and severe quality-of-life impairment in postmenopausal women: Analysis of a multicenter Latin American cross-sectional study. Menopause 2017, 24, 645-652. [CrossRef]

32. Luine, V.N. Estradiol and cognitive function: Past, present and future. Horm. Behav. 2014, 66, 602-618. [CrossRef] [PubMed]

33. Ma, S.L.; Tang, N.L.; Leung, G.T.; Fung, A.W.; Lam, L.C. Estrogen receptor $\alpha$ polymorphisms and the risk of cognitive decline: A 2-year follow-up study. Am. J. Geriatr. Psychiatry 2014, 22, 489-498. [CrossRef] [PubMed]

34. Sundermann, E.E.; Maki, P.M.; Bishop, J.R. A review of estrogen receptor alpha gene (ESR1) polymorphisms, mood, and cognition. Menopause 2010, 17, 874-886. [CrossRef] [PubMed]

35. Klinge, C.M. Estrogen receptor interaction with estrogen response elements. Nucleic Acids Res. 2001, 29, 2905-2919. [CrossRef] [PubMed]

36. Lander, E.S.; Linton, L.M.; Birren, B.; Nusbaum, C.; Zody, M.C.; Baldwin, J.; Devon, K.; Dewar, K.; Doyle, M.; FitzHugh, W.; et al. Initial sequencing and analysis of the human genome. Nature 2001, 409, 860-921. [PubMed]

37. Mangelsdorf, D.J.; Thummel, C.; Beato, M.; Herrlich, P.; Schütz, G.; Umesono, K.; Blumberg, B.; Kastner, P.; Mark, M.; Chambon, P.; et al. The nuclear receptor superfamily: The second decade. Cell 1995, 83, 835-839. [CrossRef]

38. Osterlund, H.; Keller, E.; Hurd, Y.L. Estrogen receptor gene expression in relation to neuropsychiatric disorders. Ann. N. Y. Acad. Sci. 2003, 1007, 54-63. [CrossRef]

39. Brailoiu, E.; Dun, S.L.; Brailoiu, G.C.; Mizuo, K.; Sklar, L.A.; Oprea, T.I.; Prossnitz, E.R.; Dun, N.J. Distribution and characterization of estrogen receptor $\mathrm{G}$ protein-coupled receptor 30 in the rat central nervous system. J. Endocrinol. 2007, 193, 311-321. [CrossRef]

40. Marino, M.; Galluzzo, P.; Ascenzi, P. Estrogen signaling multiple pathways to impact gene transcription. Curr. Genomics 2006, 7, 497-508. [CrossRef]

41. Menasce, L.P.; White, G.R.; Harrison, C.J.; Boyle, J.M. Localization of the estrogen receptor locus (ESR) to chromosome 6q25.1 by FISH and a simple post-FISH banding technique. Genomics 1993, 17, $263-265$. [CrossRef]

42. Enmark, E.; Pelto-Huikko, M.; Grandien, K.; Lagercrantz, S.; Lagercrantz, J.; Fried, G.; Nordenskjöld, M.; Gustafsson, J.A. Human estrogen receptor beta-gene structure, chromosomal localization, and expression pattern. J. Clin. Endocrinol. Metab. 1997, 82, 4258-4265. [PubMed]

43. Shughrue, P.J.; Lane, M.V.; Merchenthaler, I. Comparative distribution of estrogen receptor $\alpha$ - and $\beta$-mRNA in the rat central nervous system. J. Comp. Neurol. 1997, 388, 507-525. [CrossRef]

44. Österlund, M.K.; Gustafsson, J.A.; Keller, E. Estrogen Receptor (ERbeta) messenger ribonucleic Acid (mRNA) expression within the human forebrain: Distinct distribution pattern to ER mRNA. J. Clin. Endocrinol. Metab. 2000, 85, 3840-3846. [PubMed]

45. Gallagher, M.; Holland, P.C. The amygdala complex: Multiple roles in associative learning and attention. Proc. Natl. Acad. Sci. USA 1994, 91, 11771-11776. [CrossRef] [PubMed]

46. Gustafsson, J.A. Estrogen receptor beta-a new dimension in estrogen mechanism of action. J. Endocrinol. 1999, 163, 379-383. [CrossRef] [PubMed] 
47. Davachi, L.; Dobbin, I.G. Declarative Memory. Curr. Dir. Psychol. Sci. 2008, 17, 112-118. [CrossRef] [PubMed]

48. Weiser, M.J.; Foradori, C.D.; Handa, R.J. Estrogen receptor beta in the brain: From form to function. Brain Res. Rev. 2008, 57, 309-320. [CrossRef]

49. Cheng, D.; Liang, B.; Hao, Y.; Zhou, W. Estrogen receptor $\alpha$ gene polymorphisms and risk of Alzheimer's disease: Evidence from a meta-analysis. Clin. Interv. Aging 2014, 9, 1031-1038. [CrossRef]

50. Becherini, L.; Gennari, L.; Masi, L.; Mansani, R.; Massart, F.; Morelli, A.; Falchetti, A.; Gonnelli, S.; Fiorelli, G.; Tanini, A.; et al. Evidence of a linkage disequilibrium between polymorphisms in the human estrogen receptor alpha gene and their relationship to bone mass variation in postmenopausal Italian women. Hum. Mol. Gene 2000, 9, 2043-2050. [CrossRef]

51. Del Senno, L.; Aguiari, G.L.; Piva, R. Dinucleotide repeat polymorphism in the human estrogen receptor (ESR) gene. Hum. Mol. Genet. 1992, 1, 354. [CrossRef]

52. Isoe, K.; Ji, Y.; Urakami, K.; Adachi, Y.; Nakashima, K. Genetic association of estrogen receptor gene polymorphisms with Alzheimer's disease. Alzheimer's Res. 1997, 3, 195-197.

53. Brandi, M.L.; Becherini, L.; Gennar, L.; Racchi, M.; Bianchetti, A.; Nacmias, B.; Sorbi, S.; Mecocci, P.; Senin, U.; Govoni, S. Association of the estrogen receptor alpha gene polymorphisms with sporadic Alzheimer's disease. Biochem. Biophys. Res. Commun. 1999, 265, 335-338. [CrossRef] [PubMed]

54. Ji, Y.; Urakami, K.; Wada-Isoe, K.; Adachi, Y.; Nakashima, K. Estrogen receptor gene polymorphisms in patients with Alzheimer's disease, vascular dementia and alcohol-associated dementia. Dement. Geriatr. Cogn. Disord. 2000, 11, 119-122. [CrossRef] [PubMed]

55. Ryan, J.; Carrière, I.; Carcaillon, L.; Dartigues, J.F.; Auriacombe, S.; Rouaud, O.; Berr, C.; Ritchie, K.; Scarabin, P.Y.; Ancelin, M.L. Estrogen receptor polymorphisms and incident dementia: The prospective 3C study. Alzheimers Dement. 2014, 10, 27-35. [CrossRef] [PubMed]

56. Olsen, L.; Rasmussen, H.B.; Hansen, T.; Bagger, Y.Z.; Tankó, L.B.; Qin, G.; Christiansen, C.; Werge, T. Estrogen receptor alpha and risk for cognitive impairment in postmenopausal women. Psychiatr. Genet. 2006, 16, 85-88. [CrossRef] [PubMed]

57. Kravitz, H.M.; Meyer, P.M.; Seeman, T.E.; Greendale, G.A.; Sowers, M.R. Cognitive functioning and sex steroid hormone gene polymorphisms in women at midlife. Am. J. Med. 2006, 119 (Suppl. S1), S94-S102. [CrossRef] [PubMed]

58. Yaffe, K.; Lui, L.Y.; Grady, D.; Stone, K.; Morin, P. Estrogen receptor 1 polymorphisms and risk of cognitive impairment in older women. Biol. Psychiatry 2002, 51, 677-682. [CrossRef]

59. Yaffe, K.; Lindquist, K.; Sen, S.; Cauley, J.; Ferrell, R.; Penninx, B.; Harris, T.; Li, R.; Cummings, S.R. Estrogen receptor genotype and risk of cognitive impairment in elders: Findings from the Health ABC study. Neurobiol. Aging 2009, 30, 607-614. [CrossRef]

60. Chaves, A.C.; Fraga, V.G.; Guimarães, H.C.; Teixeira, A.L.; Barbosa, M.T.; Carvalho, M.D.; Mota, A.P.; Silva, I.F.; Caramelli, P.; Gomes, K.B.; et al. Estrogen receptor-alpha gene XbaI A > G polymorphism influences short-term cognitive decline in healthy oldest-old individuals. Arquivos de Neuro-Psiquiatria 2017, 75, 172-175. [CrossRef]

61. Ryan, J.; Carrière, I.; Amieva, H.; Rouaud, O.; Berr, C.; Ritchie, K.; Scarabin, P.Y.; Ancelin, M.L. Prospective analysis of the association between estrogen receptor gene variants and the risk of cognitive decline in elderly women. Eur. Neuropsychopharmacol. 2013, 23, 1763-1768. [CrossRef]

62. Goumidi, L.; Dahlman-Wright, K.; Tapia-Paez, I.; Matsson, H.; Pasquier, F.; Amouyel, P.; Kere, J.; Lambert, J.C.; Meirhaeghe, A. Study of estrogen receptor- $\alpha$ and receptor- $\beta$ gene polymorphisms on Alzheimer's disease. J. Alzheimers Dis. 2011, 26, 431-439. [CrossRef] [PubMed]

63. Solis Ortiz, S.; Pérez Luque, E.; Morado Crespo, L.; Gutiérrez Muñoz, M. Executive functions and selective attention are favored in middle aged women carriers of Val 158 allele of the catechol-o-methyltransferase gene. Behav. Brain Funct. 2010, 6, 67. [CrossRef] [PubMed]

64. Wang, B. Gender difference in recognition memory for neutral and emotional faces. Memory 2013, 21, 991-1003. [CrossRef] [PubMed]

65. Folstein, M.F.; Folstein, S.E.; McHugh, P.R. Mini Mental State: A practical method for grading the cognitive state of patients for the clinician. J. Psychiatr. Res. 1975, 12, 189-198. [CrossRef]

66. Beck, A.T.; Steer, R.A. Beck Depression Inventory; The Psychological Corporation: San Antonio, TX, USA, 1993.

67. World Medical Association Declaration of Helsinki Ethical Principles for Medical Research Involving Human Subjects. Bull. World Health Organ. 2001, 74, 373-374. 
68. Liu, W.; Shao, F.M.; Yan, L.; Cao, H.X.; Qiu, D. Polymorphisms in the gene encoding estrogen receptor alpha are associated with osteoarthritis in Han Chinese women. Int. J. Clin. Exp. Med. 2014, 7, 5772-5777. [PubMed]

69. Montagne, B.; Kessels, R.P.; De Haan, E.H.; Perrett, D.I. The Emotion Recognition Task: A paradigm to measure the perception of facial emotional expressions at different intensities. Percept. Mot. Skills 2007, 104, 589-598. [CrossRef] [PubMed]

70. Paule, M.G.; Bushnell, P.J.; Maurissen, J.P.; Wenger, G.R.; Buccafusco, J.J.; Chelonis, J.J.; Elliott, R. Symposium overview: The use of delayed matching-to-sample procedures in studies of short-term memory in animals and humans. Neurotoxicol. Teratol. 1998, 20, 493-502. [CrossRef]

71. Arntzen, E.; Steingrimsdottier, H.S. On the use of variations in a delayed matching-to-sample procedure in a patient with neurocognitive disorder. In Mental Disorder; Swahn, M.H., Palmier, J.B., Braunstein, S.M., Eds.; iConcept Press: Spring City, UT, USA, 2014; pp. 123-138. ISBN 978-1-922227-96-6.

72. Derntl, B.; Windischberger, C.; Robinson, S.; Lamplmayr, E.; Kryspin-Exner, I.; Gur, R.C.; Moser, E.; Habel, U. Facial emotion recognition and amygdala activation are associated with menstrual cycle phase. Psychoneuroendocrinology 2008, 33, 1031-1040. [CrossRef]

73. Burger, H.G.; Dudley, E.C.; Hopper, J.L.; Groome, N.; Guthrie, J.R.; Green, A.; Dennerstein, L. Prospectively measured levels of serum follicle-stimulating hormone, estradiol, and the dimeric inhibins during the menopausal transition in a population-based cohort of women. J. Clin. Endocrinol. Metab. 1999, 84, 4025-4030.

74. Gracia, C.R.; Sammel, M.D.; Freeman, E.W.; Lin, H.; Langan, E.; Kapoor, S.; Nelson, D.B. Defining menopause status: Creation of a new definition to identify the early changes of the menopausal transition. Menopause 2005, 12, 128-135. [CrossRef]

75. Jurado, S.; Villegas, M.E.; Méndez, L.; Rodríguez, F.; Loperena, V.; Varela, R. La estandarización del inventario de la depresión de Beck para los residentes de la ciudad de México. Salud Ment. 1998, 21, 36-38.

76. Desu, M.M.; Raghavarao, D. Sample Size Methodology; Academic Press: Boston, MA, USA, 1990; pp. 85-90.

77. Altman, D.G. Sample size. In Practical Statistical for Medical Research; Chapman and Hall: London, UK, 1991; pp. 455-460.

78. Triola, M.F. Elementary Statistics, 10th ed.; Pearson Addison Wesley: Boston, MA, USA, 2006; pp. 110-118.

79. Sullivan, G.M.; Feinn, R. Using effect size or why the p value is not enough. J. Grad. Med. Educ. 2012, 4, 279-282. [CrossRef] [PubMed]

80. Cohen, J. A power primer. Psychol. Bull. 1992, 112, 155-159. [CrossRef] [PubMed]

81. Lander, E.; Kruglyak, L. Genetic dissection of complex traits: Guidelines for interpreting and reporting linkage results. Nat. Genet. 1995, 11, 241-247. [CrossRef] [PubMed]

82. Santoro, N.; Randolph, J.F. Reproductive hormones and the menopause transition. Obstet. Gynecol. Clin. N. Am. 2011, 38, 455-466. [CrossRef] [PubMed]

83. Borrow, A.P.; Handa, R.J. Estrogen receptors modulation of anxiety-like behavior. Vitam. Horm. 2017, 103, 27-52. [CrossRef] [PubMed]

84. Ryan, J.; Scali, J.; Carrière, I.; Scarabin, P.Y.; Ritchie, K.; Ancelin, M.L. Estrogen receptor gene variants are associated with anxiety disorders in older women. Psychoneuroendocrinology 2011, 36, 1582-1586. [CrossRef]

85. Walf, A.A.; Koonce, C.J.; Frye, C.A. Estradiol or diarylpropionitrile decrease anxiety-like behavior of wildtype, but not estrogen receptor beta knockout, mice. Behav. Neurosc. 2008, 122, 974-981. [CrossRef]

86. Viggiano, A.; Cacciola, G.; Widmer, D.A.; Viggiano, D. Anxiety as a neurodevelopmental disorder in a neuronal subpopulation: Evidence from gene expression data. Psychiatry Res. 2015, 228, 729-740. [CrossRef]

87. Viggiano, D. The hyperactive syndrome: Metanalysis of genetic alterations, pharmacological treatments and brain lesions which increase locomotor activity. Behav. Brain Res. 2008, 194, 1-14. [CrossRef]

88. Viggiano, D.; Sadile, A.G. Hypertrophic A10 dopamine neurons in a rat model of attention-deficit hyperactivity disorder (ADHD). Neuroreport 2000, 11, 3677-3680. [CrossRef] [PubMed]

89. Derntl, B.; Kryspin-Exner, I.; Fernbach, E.; Mose, E.; Habel, U. Emotion recognition accuracy in healthy young females is associated with cycle phase. Horm. Behav. 2008, 53, 90-95. [CrossRef] [PubMed]

90. Fjeldheim, F.N.; Frydenberg, H.; Flote, V.G.; McTiernan, A.; Furberg, A.S.; Ellison, P.T.; Barrett, E.S.; Wilsgaard, T.; Jasienska, G.; Ursin, G.; et al. Polymorphisms in the estrogen receptor alpha gene (ESR1), daily cycling estrogen and mammographic density phenotypes. BMC Cancer 2016, 16, 77. [CrossRef] [PubMed]

91. Baddeley, A. Working memory. Curr. Biol. 2010, 20, R136-R140. [CrossRef] [PubMed] 
92. Joffe, H.; Hall, J.E.; Gruber, S.; Sarmiento, I.A.; Cohen, L.S.; Yurgelun-Todd, D.; Martin, K.A. Estrogen therapy selectively enhances prefrontal cognitive processes: A randomized, double-blind, placebo controlled study with functional magnetic resonance imaging in perimenopausal and recently postmenopausal women. Menopause 2006, 13, 411-422. [CrossRef] [PubMed]

93. Keenan, P.A.; Ezzat, W.H.; Ginsburg, K.; Moore, G.J. Prefrontal cortex as the site of estrogen's effect on cognition. Psychoneuroendocrinology 2001, 26, 577-590. [CrossRef]

94. Wang, A.C.; Hara, Y.; Janssen, W.G.; Rapp, P.R.; Morrison, J.H. Synaptic estrogen receptor-alpha levels in prefrontal cortex in female rhesus monkeys and their correlation with cognitive performance. J. Neurosci. 2010, 30, 12770-12776. [CrossRef]

95. McEwen, B.S.; Milner, T.A. Understanding the broad influence of sex hormones and sex differences in the brain. J. Neurosci. Res. 2017, 95, 24-39. [CrossRef]

96. McEwen, B.C.; Akama, K.T.; Spencer-Segal, J.L.; Milner, T.A.; Waters, E.M. Estrogen effects on the brain: Actions beyond the hypothalamus via novel mechanisms. Behav. Neurosci. 2012, 126, 4-16. [CrossRef]

97. Elsabagh, S.; Hartley, D.E.; File, S.E. Cognitive function in late versus early postmenopausal stage. Maturitas 2007, 56, 84-93. [CrossRef] [PubMed]

98. McCarrey, A.C.; Resnick, S.M. Postmenopausal hormone therapy and cognition. Horm. Behav. 2015, 74, 167-172. [CrossRef] [PubMed]

99. Rentz, D.M.; Weiss, B.K.; Jacobs, E.G.; Cherkerzian, S.; Klibanski, A.; Remington, A.; Aizley, H.; Goldstein, J.M. Sex differences in episodic memory in early midlife: Impact of reproductive aging. Menopause 2017, 24, 400-408. [CrossRef] [PubMed]

100. Bean, L.A.; Ianov, L.; Foster, T.C. Estrogen receptors, the hippocampus, and memory. Neuroscientist 2014, 20, 534-545. [CrossRef] [PubMed]

101. Ribeiro, M.V.; Hasten-Reiter Júnior, H.N.; Ribeiro, E.A.; Jucá, M.J.; Barbosa, F.T.; Sousa-Rodrigues, C.F. Association between visual impairment and depression in the elderly: A systematic review. Arq. Bras. Oftalmol. 2015, 78, 197-201. [CrossRef] [PubMed]

102. Loprinzi, P.D.; Codey, K. Influence of visual acuity on anxiety, panic and depression disorders among young and middle age adults in the United States. J. Affect. Disord. 2014, 167, 8-11. [CrossRef] [PubMed]

103. Renaud, J.; Bédard, E. Depression in the elderly with visual impairment and its association with quality of life. Clin. Interv. Aging 2013, 8, 931-943. [CrossRef]

104. Ryan, J.; Scali, J.; Carrière, I.; Peres, K.; Rouaud, O.; Scarabin, P.Y.; Ritchie, K.; Ancelin, M.L. Estrogen receptor alpha gene variants and major depressive episodes. J. Affect. Disord. 2012, 136, 1222-1226. [CrossRef]

105. Lymer, J.M.; Sheppard, P.A.S.; Kuun, T.; Blackman, A.; Jani, N.; Mahbub, S.; Choleris, E. Estrogens and their receptors in the medial amygdala rapidly facilitate social recognition in female mice. Psychoneuroendocrinology 2018, 89, 30-38. [CrossRef]

106. Gasbarri, A.; Tavares, M.C.; Rodriguez, R.C.; Tomaz, C.; Pompili, A. Estrogen, cognitive functions and emotion: An overview on humans, non-human primates and rodents in reproductive years. Rev. Neurosci. 2012, 23, 587-606. [CrossRef]

107. Greenspan, H.; Levitt, W.G.; Berman, J.; Hussain, A.; Waseem, S.; Nandu, B.; Nehru, V.; Jaquish, C. Worsening depression in a patient with a granulosa cell tumor. Psychiatr. Ann. 2013, 43, 377-379. [CrossRef]

108. Tsai, S.J.; Wang, Y.C.; Hong, C.J.; Chiu, H.J. Association study of oestrogen receptor alpha gene polymorphism and suicidal behaviours in major depressive disorder. Psychiatr. Genet. 2003, 13, 19-22. [CrossRef] [PubMed]

109. Keyes, K.; Agnew-Blais, J.; Roberts, A.L.; Hamilton, A.; De Vivo, I.; Ranu, H.; Koenen, K. The role of allelic variation in estrogen receptor genes and major depression in the Nurses Health Study. Soc. Psychiatry Psychiatr. Epidemiol. 2015, 50, 1893-1904. [CrossRef] [PubMed]

110. Różycka, A.; Słopień, R.; Słopień, A.; Dorszewska, J.; Seremak-Mrozikiewicz, A.; Lianeri, M.; Maciukiewicz, M.; Warenik-Szymankiewicz, A.; Grzelak, T.; Kurzawińska, G.; et al. The MAOA, COMT, MTHFR and ESR1 gene polymorphisms are associated with the risk of depression in menopausal women. Maturitas 2016, 84, 42-54. [CrossRef] [PubMed]

111. Wedrén, S.; Lovmar, L.; Humphreys, K.; Magnusson, C.; Melhus, H.; Syvänen, A.C.; Kindmark, A.; Landegren, U.; Fermér, M.L.; Stiger, F.; et al. Oestrogen receptor alpha gene haplotype and postmenopausal breast cancer risk: A case control study. Breast Cancer Res. 2004, 6, R437-R449. [CrossRef] [PubMed] 
112. Gennari, L.; Merlotti, D.; De Paola, V.; Calabrò, A.; Becherini, L.; Martini, G.; Nuti, R. Estrogen receptor gene polymorphisms and the genetics of osteoporosis: A HuGE review. Am. J. Epidemiol. 2005, 161, 307-320. [CrossRef] [PubMed]

113. Freeman, E.W.; Sammel, M.D.; Lin, H.; Nelson, D.B. Associations of hormones and menopausal status with depressed mood in women with no history of depression. Arch. Gen. Psychiatry 2006, 63, 375-382. [CrossRef]

114. Deecher, D.; Andree, T.H.; Sloan, D.; Schechter, L.E. From menarche to menopause: Exploring the underlying biology of depression in women experiencing hormonal changes. Psychoneuroendocrinology 2008, 33, 3-17. [CrossRef]

115. Solís-Ortiz, S.; Pérez-Luque, E.; Pacheco-Zavala, P. Resting EEG activity and ovarian hormones as predictors of depressive symptoms in postmenopausal women without a diagnosis of major depression. Psychology 2012, 3, 834-840. [CrossRef]

116. Osterlund, M.K.; Witt, M.R.; Gustafsson, J.A. Estrogen action in mood and neurodegenerative disorders: Estrogenic compounds with selective properties-the next generation of therapeutics. Endocrine 2005, 28, 235-242. [CrossRef]

117. Amin, Z.; Canli, T.; Epperson, C.N. Effect of estrogen-serotonin interactions on mood and cognition. Behav. Cogn. Neurosci. Rev. 2005, 4, 43-58. [CrossRef] [PubMed]

118. Borrow, A.P.; Cameron, N.M. Estrogenic mediation of serotonergic and neurotrophic systems: Implications for female mood disorders. Prog. Neuropsychopharmacol. Biol. Psychiatry 2014, 3, 13-25. [CrossRef] [PubMed]

119. Kunimura, Y.; Iwata, K.; Iijima, N.; Kobayashi, M.; Ozawa, H. Effect of sex steroid hormones on the number of serotonergic neurons in rat dorsal raphe nucleus. Neurosci. Lett. 2015, 594, 127-132. [CrossRef] [PubMed]

120. Merens, W.; Willem Van der Does, A.J.; Spinhoven, P. The effects of serotonin in manipulations on emotional information processing and mood. J. Affect. Disord. 2007, 103, 43-62. [CrossRef] [PubMed]

121. Leppänen, J.M. Emotional information processing in mood disorders: A review of behavioral and neuroimaging findings. Curr. Opin. Psychiatry 2006, 19, 34-39. [CrossRef] [PubMed]

122. Bourke, C.; Douglas, K.; Porter, R. Processing of facial emotion expression in major depression: A review. Aust. N. Z. J. Psychiatry 2010, 44, 681-696. [CrossRef] [PubMed]

123. Anderson, I.M.; Shippen, C.; Juhasz, G.; Chase, D.; Thomas, E.; Downey, D.; Toth, Z.G.; Lloyd-Williams, K.; Elliott, R.; Deakin, J.F. State-dependent alteration in face emotion recognition in depression. Br. J. Psychiatry 2011, 198, 302-308. [CrossRef] [PubMed]

124. Biyik, U.; Keskin, D.; Oguz, K.; Akdeniz, F.; Gonul, A.S. Facial emotion recognition in remitted depressed women. Asian J. Psychiatr. 2015, 17, 111-113. [CrossRef]

125. Shafir, T.; Love, T.; Berent-Spillson, A.; Persad, C.C.; Wang, H.; Reame, N.K.; Frey, K.A.; Zubieta, J.K.; Smith, Y.R. Postmenopausal hormone use impact on emotion processing circuitry. Behav. Brain Res. 2012, 226, 147-153. [CrossRef]

126. Love, T.; Smith, Y.R.; Persad, C.C.; Tkaczyk, A.; Zubieta, J.K. Short-term hormone treatment modulates emotion response circuitry in postmenopausal women. Fertil. Steril. 2010, 93, 1929-1937. [CrossRef]

127. Bryant, H.U. Mechanism of action and preclinical profile of raloxifene, a selective estrogen receptor modulation. Rev. Endocr. Metab. Disord. 2001, 2, 129-138. [CrossRef] [PubMed]

128. Kindler, J.; Weickert, C.S.; Schofield, P.R.; Lenroot, R.; Weickert, T.W. Raloxifene increases prefrontal activity during emotional inhibition in schizophrenia based on estrogen receptor genotype. Eur. Neuropsychopharmacol. 2016, 26, 1930-1940. [CrossRef] [PubMed]

(C) 2018 by the authors. Licensee MDPI, Basel, Switzerland. This article is an open access article distributed under the terms and conditions of the Creative Commons Attribution (CC BY) license (http://creativecommons.org/licenses/by/4.0/). 